Article

\title{
Proteomic Evaluation of Insecticidal Action of Phosphine on Green Peach Aphids, Myzus persicae
}

\author{
Kyeongnam Kim ${ }^{1}{ }^{\mathbb{D}}$, Jeong Sun Park ${ }^{2}$, Jeong Oh Yang ${ }^{2, \dagger}$ and Sung-Eun Lee ${ }^{1, *, \dagger}$ \\ School of Applied Biosciences, Kyungpook National University, Daegu 41566, Korea; kn1188@knu.ac.kr \\ 2 Animal and PlantQuarantine Agency (APQA), Gimcheon 39660, Korea; jungsun5009@naver.com (J.S.P.); \\ joyang12@korea.kr (J.O.Y.) \\ * Correspondence: selpest@knu.ac.kr \\ + These authors contributed equally to this work.
}

Received: 21 August 2018; Accepted: 28 September 2018; Published: 29 September 2018

Featured Application: The specific application of the research aims to control insect pests by fumigants.

\begin{abstract}
Phosphine $\left(\mathrm{PH}_{3}\right)$ fumigation is one of the best alternatives to methyl bromide for regulating insect pests during storage and shipping. Recently, this treatment has been applied to other agricultural insect pests, including Myzus persicae. To understand the mode of $\mathrm{PH}_{3}$ toxicity in M. persicae, proteomic analyses using liquid-chromatography tandem mass spectrometry were conducted to measure comparative protein expression levels between $\mathrm{PH}_{3}$-treated samples and controls. $\mathrm{PH}_{3}$ treatment increased $\mathrm{NADH}$ dehydrogenase (ubiquinone) flavoprotein 1 , mitochondrial-like (complex I) expression, but decreased complex II and ATPases in the mitochondrial electron transport chain (ETC) of M. persicae. Glucosidase and antimicrobial proteins such as lysozymes showed enhanced expression in $\mathrm{PH}_{3}$-treated $M$. persicae. Some regulatory proteins related to apoptosis were more abundant in $\mathrm{PH}_{3}$-treated M. persicae. Biochemical activities of acetylcholinesterase (AChE) and cytochrome c oxidase (COX) were also measured because these enzymes are known to be targeted by $\mathrm{PH}_{3}$. Only COX activity decreased in relation to increasing $\mathrm{PH}_{3}$ concentrations in adult $M$. persicae. The expression of six selected genes were determined in relation to $\mathrm{PH}_{3}$ treatments. No two-fold changes in the expression of the six genes was observed. Thus, $\mathrm{PH}_{3}$ toxicity caused disruption in the ETC and glucose supply, as well as dis-regulation of apoptosis in M. persicae.
\end{abstract}

Keywords: phosphine; proteomic analysis; complex I; electron transport chain; glucosidase

\section{Introduction}

Tablets of various phosphine $\left(\mathrm{PH}_{3}\right)$-containing chemicals, including aluminum phosphide, release $\mathrm{PH}_{3}$ s, which have been extensively used as fumigants for the control of insect pests, thereby minimizing trading risks and protecting stored agricultural products [1]. In addition, $\mathrm{PH}_{3}$ s have been introduced as an alternative to methyl bromide for controlling adult greenhouse thrips (Heliothrips haemorrhoidalis), adult aphids (Myzus persicae), and light brown apple moth larvae (Epipyas postvittana), in cut flowers [2]. Based on the trials, the most effective formulation for aphids was $1000 \mu \mathrm{L} / \mathrm{L} \mathrm{PH}_{3}+33 \% \mathrm{CO}_{2}$ for $4 \mathrm{~h}$, while all tested insects were killed within $36 \mathrm{~h}$ of exposure [2].

Furthermore, M. persicae can be controlled by Brassicacaeae ethyl ester oils [3], a certain wavelength of light-emitting diodes [4], and biologically using banker plants with Aphidius colemani [5]. Recently, ethyl formate (EF) was used to control M. persicae by fumigation and this fumigant induced 
2-fold cytochrome c oxidase (COX) activity in comparison with the control [6]. Stewart and Mon [7] introduced the use of EF fumigation to protect film-wrapped lettuces from M. persicae.

Interestingly, $\mathrm{PH}_{3}$ and $\mathrm{EF}$ have been combined for use in the control of insect pests. The combination of $\mathrm{PH}_{3}$ and EF effectively killed Aphis gossypii, the cotton aphid [8], whereas individual treatments with $\mathrm{PH}_{3}$ fumigation over short periods of time or at low EF concentrations provided relatively low eradication rates. The combination may also completely control the eggs of Planococcus citri (Hemiptera: Pseudococcidae) on pineapples, when applied at concentrations of 25.1/1.0 (EF/ $\left.\mathrm{PH}_{3}\right) \mathrm{mg} / \mathrm{L}$ at $8{ }^{\circ} \mathrm{C}$ for $4 \mathrm{~h} \mathrm{[9].}$

This combined fumigation has been used to eradicate $M$. persicae efficiently and may hinder the development of $\mathrm{PH}_{3}$ and/or EF resistance in M. persicae. $\mathrm{PH}_{3}$ resistance in various insect pests have been reported throughout the world in various insect species, including Rhyzopertha dominica, Tribolium castaneum, and Cryptolestes ferrugineus [10-12], leading farmers and fumigators to explore new fumigation tools to control $\mathrm{PH}_{3}$-resistant insect pests in storage facilities [13,14].

This study assessed the acute toxicity in M. persicae caused by $\mathrm{PH}_{3}$ to determine its lethal concentration $\mathrm{LC}_{10}$ and $\mathrm{LC}_{50}$ values. Regarding the acute toxicity, activities of two enzymes such as acetylcholinesterase (AChE) and cytochrome c oxidase (COX) were measured to know the actual target sites of $\mathrm{PH}_{3}$. AChE and $\mathrm{COX}$ have been known to be the target site of an organophosphorus insecticide and $\mathrm{PH}_{3}$, respectively. Besides, expression levels of six genes responsible for expressing cytochrome P450 6CY3 (cyp6cy3), farnesyl diphosphate synthase 1 (fps1), acetylcholinesterase (ache), voltage gated sodium channel subunit 1 (para), nicotinic acetylcholine receptor alpha 3 subunit (ni-acr), and ecdysone receptor (ecr) were also measured to understand effects of $\mathrm{PH}_{3}$ on metabolism, neurotransmission system, and growth in M. persicae. Finally, overall protein expression levels were compared between the $\mathrm{PH}_{3}$-treated adults of $M$. persicae and the control using liquid-chromatography tandem mass spectrometry (LC-MS/MS) to find further biochemical reasons for the explication of the toxic effect by $\mathrm{PH}_{3}$.

\section{Material and Methods}

\subsection{Chemicals}

$\mathrm{PH}_{3}$ was obtained as ECO2Fume ${ }^{\mathrm{TM}}\left(2 \% \mathrm{PH}_{3}+98 \% \mathrm{CO}_{2}\right)$ from Cytec (Sydney, Australia). Acetylthiocholine iodide (ATChI), bovine serum albumin (BSA), cytochrome c, 5,5'-dithiobis (2-nitrobezoic acid) were purchased from Sigma-Aldrich (St. Louis, MO, USA). The DEPC-treated water was purchased from Biosesang (Seongnam, Korea). The Rotor-Gene SYBR Green PCR Kit and QIAzol Lysis reagent were purchased from Qiagen (Düsseldorf, Germany), and the Maxima First Strand cDNA Synthesis Kit with dsDNase was purchased from Thermo Fisher Scientific (Waltham, MA, USA).

\subsection{Insect Strain and Breeding}

Adults of Myzus persicae acquired from Quarantine and Inspection Agency (Gimcheon, Korea) were placed on Chinese cabbages, which were grown to a 5 to $7 \mathrm{~cm}$ leaf length, for feeding and breeding 17 days after seeding. Chinese cabbages were maintained in a glass greenhouse at $30 \pm 1{ }^{\circ} \mathrm{C}$ and a relative humidity of $30 \%$. The $M$. persicae were placed and bred on Chinese cabbages in 5 pots in an acrylic growth cage $(30 \times 30 \times 45 \mathrm{~cm})$ at $25 \pm 1^{\circ} \mathrm{C}$ and a relative humidity of $50-60 \%$.

\subsection{Fumigation Assay of $\mathrm{PH}_{3}$}

A fumigation bioassay using a concentration of 0.01 to $1.0 \mathrm{mg} / \mathrm{L}$ of $\mathrm{PH}_{3}\left(\mathrm{ECO} 2 \mathrm{Fume}^{\mathrm{TM}}\right.$ : $2 \% \mathrm{PH}_{3}+98 \% \mathrm{CO}_{2}$, Cytec, Sydney, Australia) was performed with 30 nymphs or adults of M. persicae placed in desiccators (12 L, Duran, Germany) sealed with glass stoppers containing a septum of filter paper for $20 \mathrm{~h}$ for $\mathrm{PH}_{3}$ at $20{ }^{\circ} \mathrm{C}$. A 12-L desiccator (Bibby Scientific, Stone, UK, Cat. No. FE 12L/4) equipped with a lid fitted with a septum injection system (Alltech Crop Science, Nicholasville, KY, 
USA, Cat. No. 95326) was used for the fumigation of M. persicae. The volume of each desiccator was measured by weighing the amount of water at $20^{\circ} \mathrm{C}$. A magnetic bar was placed at the bottom of each desiccator to stir the gas and ensure even distribution of the fumigant.

\subsection{Measurement of $\mathrm{PH}_{3}$ Concentrations}

To monitor the fumigation concentration in the $12-\mathrm{L}$ desiccator, $50-\mathrm{mL}$ gas samples were drawn with a syringe from the chamber and stored in 1-L Tedlar ${ }^{\circledR}$ gas sampling bags (SKC, Dorset, UK) and analyzed, typically within $10 \mathrm{~min}$ of sampling. The concentration of $\mathrm{PH}_{3}$ was monitored at $10 \mathrm{~min}$ and 1, 3, 6, and $20 \mathrm{~h}$. The subsequent concentration was determined using an Agilent GC 7890A equipped with a flame photometric detector (FPD) and HP-PLOT/Q (30 m $\times 530 \mu \mathrm{m} \times 40 \mu \mathrm{m}$; Agilent, Santa Clara, CA, USA) operating in split mode (10:1). The injector and oven temperatures were set to $200{ }^{\circ} \mathrm{C}$. The detector temperature was $250{ }^{\circ} \mathrm{C}$. The injection volume and flow rate were $20 \mu \mathrm{L}$ and $5 \mathrm{~mL} / \mathrm{min}$, respectively. The concentrations of $\mathrm{PH}_{3}$ were calculated based on peak areas against external standards.

\subsection{Determination of the Concentration $\times$ Time $(C T)$ of Fumigants}

The concentrations of the fumigants were monitored at timed intervals over the exposure period and used to calculate the CT (concentration $\times$ time) values using Equation (1).

$$
C T=\sum\left(C_{i}+C_{i+1}\right)\left(t_{i+1}-t_{i}\right) / 2
$$

where $C$ is the concentration of the fumigant $(\mathrm{mg} / \mathrm{L}) ; \mathrm{t}$ is the time of exposure $(\mathrm{h}) ; \mathrm{i}$ is the order of measurement; and $\mathrm{CT}$ is the concentration $\times$ time $(\mathrm{mg} \mathrm{h} / \mathrm{L})$

$\mathrm{PH}_{3}$ toxicity against M. persicae was described as the mortality of $>30 \mathrm{M}$. persicae adults for at least three different $\mathrm{CT}$ values based on an average and SE (standard error) analysis. We calculated the concentration $\times$ time values for $10 \%$ (CT 10) and 50\% mortality (CT 50), as well as the time values for $10 \%$ and $50 \%$ mortality due to $\mathrm{PH}_{3}$ and EF fumigation based on a Probit analysis using the SPSS statistics software (version 23.0).

\subsection{Protein Extraction}

Two groups of M. persicae were collected after fumigation assay of $\mathrm{PH}_{3}$, and immediately frozen at $-70{ }^{\circ} \mathrm{C}$. The frozen $M$. persicae (50 individuals) were homogenized with Tris-buffer containing $500 \mathrm{mM}$ sucrose ( $\mathrm{pH}$ 7.4) using pencil-type homogenizer. The homogenized solution was centrifuged at $600 \times g$ and $4{ }^{\circ} \mathrm{C}$ for $10 \mathrm{~min}$. The supernatant (whole protein extract) was centrifuged at $10,000 \times g$ and $4^{\circ} \mathrm{C}$ for $15 \mathrm{~min}$, the pellet containing mitochondria was named "the mitochondrial fraction," and the supernatant containing the soluble cytosolic portion was named "the S9 fraction". Protein quantification was performed using the Bradford Assay with the Protein Assay Dye Reagent Concentrate (Bio-Rad, Hercules, CA, USA), and the protein standard curves were constructed using varying concentrations of BSA according to the manufacturer's recommendations.

\subsection{Enzyme Assay}

The reduced cytochrome $\mathrm{c}$ was prepared as follows for use as the substrate of COX. Cytochrome $\mathrm{c}$ $(2.7 \mathrm{mg}$ ) was weighed and dissolved in $1 \mathrm{~mL}$ of distilled water. To this solution, $5 \mu \mathrm{L}$ of $0.1 \mathrm{M}$ 1,4-Dithiothreitol (DTT) was added as a reducing agent and allowed to react at room temperature for 30 min until the color changed from dark brown to pale pink. The fully reduced cytochrome c solution was diluted 10-fold with Tris-buffer $(120 \mathrm{mM} \mathrm{KCl}, 10 \mathrm{mM}$ Tris- $\mathrm{HCl}, \mathrm{pH} 7.4)$ and used as the reaction solution of COX. The mitochondrial fraction was properly diluted with Tris-buffer containing $500 \mathrm{mM}$ sucrose ( $\mathrm{pH}$ 7.4). To measure the activity of COX, $20 \mu \mathrm{L}$ of the mitochondrial fraction containing $0.0012 \mathrm{mg}$ of proteins and $180 \mu \mathrm{L}$ of the reaction solution were mixed in a 96-well plate at $25^{\circ} \mathrm{C}$ and measured at $550 \mathrm{~nm}$ for $30 \mathrm{~min}$ at $30 \mathrm{~s}$ intervals. 
Acetylcholinesterase (AChE) activity was determined using the Ellman method [15] at $412 \mathrm{~nm}$. These enzyme activities were measured using the S9 fraction as described above. Enzyme activities were expressed in units $/ \mathrm{mg}$, meaning one unit would react with $1 \mu \mathrm{M}$ substrate per min at $25^{\circ} \mathrm{C}$ and $\mathrm{pH}$ 7.4. The data were expressed as mean \pm standard deviation (SD) and analyzed using a one-way analysis of variance (ANOVA) and Tukey's test as a post-hoc test in SPSS (version 23.0). All experiments were independently performed in triplicate.

\subsection{RNA Extraction and RT-qPCR}

M. persicae (50 individuals) in two groups were independently collected and frozen immediately at $-70^{\circ} \mathrm{C}$. M. persicae were rinsed twice with DEPC-treated water and homogenized using pencil-type homogenizer. The DEPC-treated water was purchased from Biosesang (Seongnam, Korea). To the homogenized sample, $1 \mathrm{~mL}$ of QIAzol lysis reagent (Qiagen, Düsseldorf, Germany) was added and incubated on ice for $20 \mathrm{~min}$. The total RNA of each M. persicae group was extracted according to the manufacturer's protocol. The quality of total RNA was determined by measuring its A260/280 nm ratio (1.8-2.0) and checked by agarose gel electrophoresis. The Complementary DNA (cDNA) was immediately synthesized using the Maxima First Strand cDNA Synthesis Kit for RT-qPCR (Thermo Fisher Scientific Inc., Waltham, MA, USA) and stored at $-20^{\circ} \mathrm{C}$. A quantitative PCR (qPCR) was performed with a CYBR ${ }^{\circledR}$ Green kit using Rotor-gene ${ }^{\circledR} \mathrm{Q}$ (Qiagen, Düsseldorf, Germany) following the manufacturer's recommendations: $95^{\circ} \mathrm{C}$ for $10 \mathrm{~min}$ (hold), followed by 40 cycles of $95^{\circ} \mathrm{C}$ for $10 \mathrm{~s}, 60^{\circ} \mathrm{C}$ for $15 \mathrm{~s}$, and $72{ }^{\circ} \mathrm{C}$ for $20 \mathrm{~s}$, and then an increase of $1{ }^{\circ} \mathrm{C}$ from $72{ }^{\circ} \mathrm{C}$ to $95^{\circ} \mathrm{C}$ (melt). The primers for M. persicae were designed using Primer-BLAST (Ye et al., 2012) and are listed in Table S1. The beta-actin $(a c t b)$ and ribosomal protein S2 (rps2) were used to normalize the expression level of the gene of interest (GOI). The results of RT-qPCR were expressed using the $\Delta \Delta C$ t method [16] and analyzed using a one-way ANOVA and Tukey's test as a post-hoc test using the SPSS statistics software (version 23.0). All experiments were independently performed in triplicate.

\subsection{Protein Preparation for Proteomics}

The whole protein extract containing the mitochondrial fraction was obtained from M. persicae, following the same procedure mentioned in Section 2.6. The Tris-buffer containing $500 \mathrm{mM}$ sucrose (pH 7.4) and Protease Inhibitor Cocktail Set I (Calbiochem, San Diego, CA, USA) was used to avoid protein degradation during protein extraction. The protein extracts were denatured by incubating them with $50 \mathrm{mM}$ ammonium bicarbonate buffer ( $\mathrm{pH} 7.8$ ) containing $6 \mathrm{M}$ Urea for $3 \mathrm{~h}$ at room temperature. The denatured protein extracts were incubated with $10 \mathrm{mM}$ dithiothreitol for $2 \mathrm{~h}$ at room temperature to reduce their disulfide bonds. Subsequently, the reduced protein extracts were reacted first with iodoacetamide (IAA) for $1 \mathrm{~h}$ and then with trypsin at $37^{\circ} \mathrm{C}$ in a shacking incubator for $18 \mathrm{~h}$. The reacted samples were desalted using the Sep-Pac C18 cartridges (Waters Co., Milford, MA, USA) according to the manufacturer's protocol.

\subsection{Proteomic Analysis Using a Nano-LC-ESI-MS/MS}

A Thermo Scientific Q Exactive Hybrid Quadrupole-Orbitrap (Thermo Fisher Scientific Inc., Waltham, MA, USA) equipped with Dionex U 3000 RSLCnano HPLC system was used for proteomic analyses. The mass spectrometric analyses were performed with a nano-electrospray ionization source (ESI) and a fused silica emitter tip (New Objective, Woburn, MA, USA). The water/acetonitrile (98:2 $v / v$ ) solution containing $0.1 \%$ formic acid was used as the aqueous mobile phase. The samples were trapped on an Acclaim PepMap 100 trap column $(100 \mu \mathrm{m} \times 2 \mathrm{~cm}$, nanoViper C18, $5 \mu \mathrm{m}, 100 \AA)$ and washed for $6 \mathrm{~min}$ at a flow rate of $4 \mu \mathrm{L} / \mathrm{min}$ and then separated on an Acclaim PepMap 100 capillary column $(75 \mu \mathrm{m} \times 15 \mathrm{~cm}$, nanoViper $\mathrm{C} 18,3 \mu \mathrm{m}, 100 \AA)$ at a flow rate of $300 \mathrm{~mL} / \mathrm{min}$. The resulting peptides were electro-sprayed through a coated silica tip at an ion spray voltage of $2000 \mathrm{eV}$. The mass data were analyzed using Proteome Discoverer 1.4, MaxQuant 1.6, and Scaffold 4.8.4 against the 
protein databases for M. persicae. Significant differences between two groups of data were obtained using Student's $t$-test $(p<0.05)$.

\section{Results}

\subsection{Susceptibility of M. persicae under $\mathrm{PH}_{3}$ Treatments and Biochemical Changes}

Lethal concentration values due to $\mathrm{PH}_{3}$ treatment are displayed in Figure 1. There were no dramatic changes in LCT values between developmental stages of M. persicae. However, adults M. persicae were slightly more susceptible to $\mathrm{PH}_{3}$ fumigation than aphid nymphs.

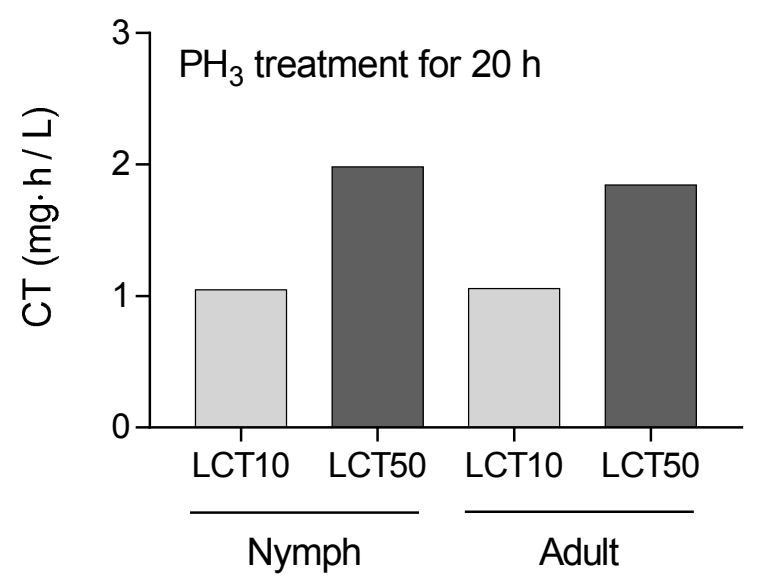

Figure 1. Effects of phosphine fumigation on the different developmental stages of Myzus persicae. Lethal concentration time (LCT) values are obtained using Equation (1). More details in mortality are shown in Figure S1 and Table S2.

One of the known target sites of $\mathrm{PH}_{3}$ fumigation in insect pests is $\mathrm{COX}$; its biochemical activity was measured using a substrate, cytochrome $\mathrm{c}$, after the $\mathrm{PH}_{3}$ treatments, corresponding to the $\mathrm{LCT}_{10}$ and $\mathrm{LCT}_{50}$ values in comparison with that of the control (Figure 2A). Cytochrome c oxidase activities in M. persicae nymphs were not affected by $\mathrm{PH}_{3}$ treatment but decreased in M. persicae adults as $\mathrm{PH}_{3}$ concentrations increased. These changes were statistically different, but they did not increase by up to 2-fold. The effects of $\mathrm{PH}_{3}$ fumigation on the biochemical activities of another well-known target of organophosphorus insecticides such as malathion and fenitrothion, i.e., AChE, was also measured in M. persicae using acetylthiocholine iodide (ATChI). There was no effect of $\mathrm{PH}_{3}$ treatments on $\mathrm{AChE}$ (Figure 2B) probably because its expression was not related to $\mathrm{PH}_{3}$ toxicity in M. persicae.

Expression levels of six genes in M. persicae: cytochrome P450 (CYP6CY3) (cyp6cy3), farnesyl diphosphate synthase 1 (fps1), acetylcholinesterase (ache), voltage gated sodium channel subunit 1 (para), nicotinic acetylcholine receptor alpha 3 (ni-acr), and ecdysone receptor (ecr), were determined in response to $\mathrm{PH}_{3}$ fumigation (Figure 3). In M. persicae nymphs, ni-acr, fps1, para, and ecr genes were upregulated after $\mathrm{PH}_{3}$ treatments (Figure 3). Similarly, in adult M. persicae, ni-acr and ecr were upregulated, whereas fps1 gene was down-regulated after $\mathrm{PH}_{3}$ treatments.

The expression of the tested genes did not increase by 2-fold in comparison with that in the control, but their expressions were statistically different in the two concentrations. 
(A)
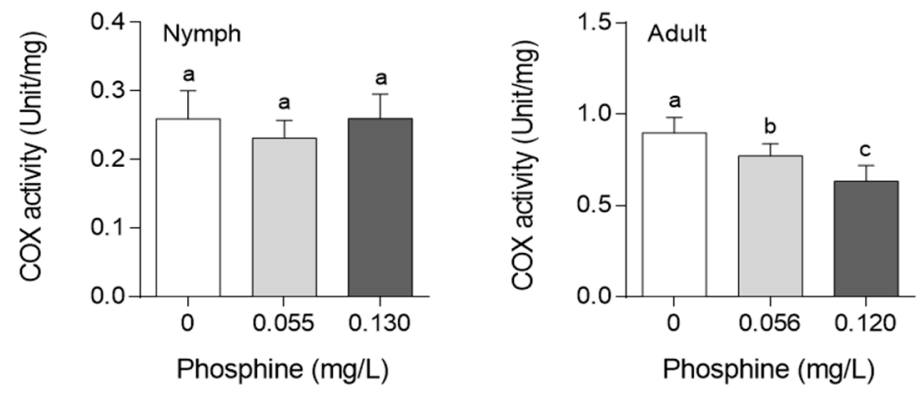

(B)
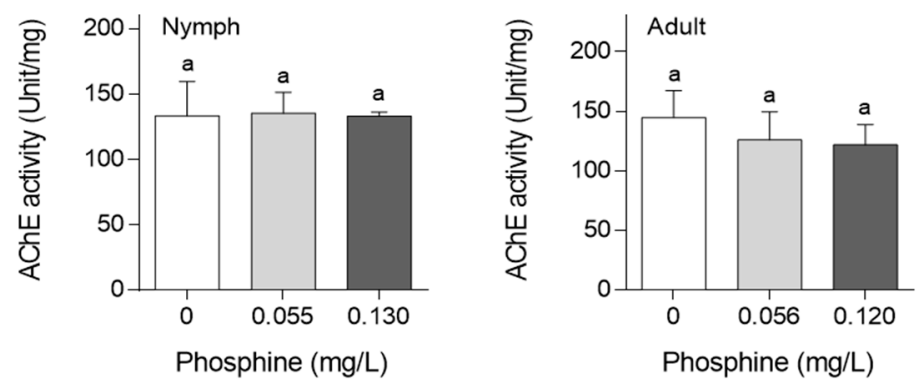

Figure 2. Enzyme assays in the two different developmental stages of Myzus persicae (nymphs and adults) after the phosphine treatment. (A) Cytochrome c oxidase (COX); (B) Acetylcholinesterase (AChE). The enzyme activities were expressed as unit/mg of the insect. Different letters on the bars indicate statistical differences between phosphine-treated samples and the control $(p<0.05)$. Treated concentrations were equivalent to $\mathrm{LC}_{10}(0.055 \mathrm{mg} / \mathrm{L}$ for nymphs or $0.056 \mathrm{mg} / \mathrm{L}$ for adults $)$ and $\mathrm{LC}_{50}$ ( $0.130 \mathrm{mg} / \mathrm{L}$ for nymphs or $0.120 \mathrm{mg} / \mathrm{L}$ for adults) values.
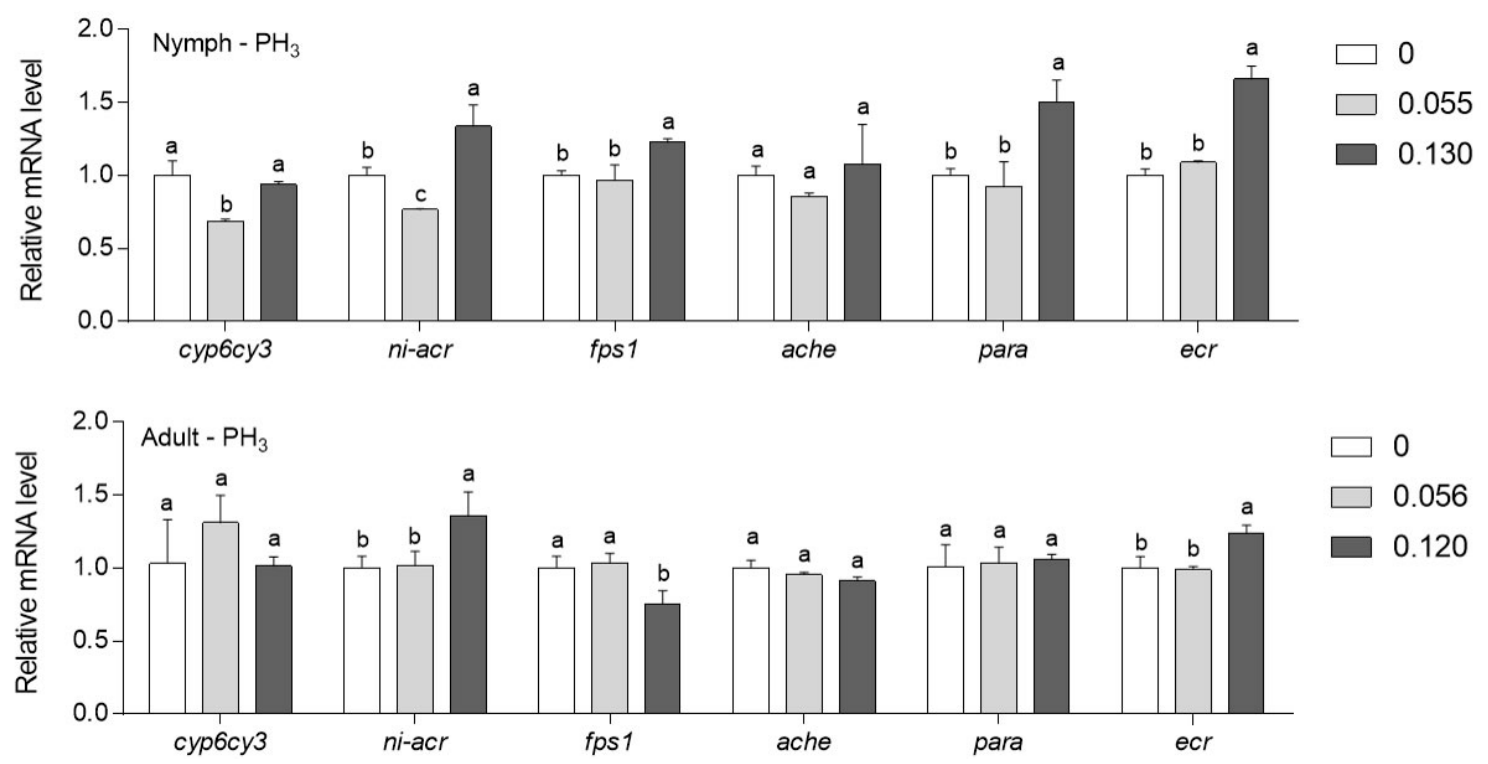

Figure 3. Gene expressions in the phosphine-treated $M$. persicae determined by RT-qPCR. Six gene primers are listed in Table S1. Different letters on the bars indicate statistical differences between phosphine-treated samples and the control $(p<0.05)$. Statistic differences were tested using one-way ANOVA and Tukey's test as a post-hoc test. Treated concentrations were equivalent to $\mathrm{LC}_{10}$ ( $0.055 \mathrm{mg} / \mathrm{L}$ for nymphs or $0.056 \mathrm{mg} / \mathrm{L}$ for adults) and $\mathrm{LC}_{50}(0.130 \mathrm{mg} / \mathrm{L}$ for nymphs or $0.120 \mathrm{mg} / \mathrm{L}$ for adults) values. 


\subsection{Proteomic Changes in M. persicae after $\mathrm{PH}_{3}$ Treatment}

A total of 1692 proteins were identified in the $\mathrm{PH}_{3}$-treated and non-chemically treated M. persicae. Among them, 49 proteins were up- and down-regulated in the $\mathrm{PH}_{3}$-treated $M$. persicae, while 13 proteins were newly expressed or could not be detected after $\mathrm{PH}_{3}$ treatment (Figures 4 and 5, Tables S3 and S4). Folds in expression levels of proteins identified in the $\mathrm{PH}_{3}$-treated $M$. persicae varied widely and increases by at least 2-fold in comparison with that in the control were considered in this study. Some proteins with small increases were ignored in the study, even if they were statistically significant.

\section{(A) Energy metabolism : Electron transport chain}
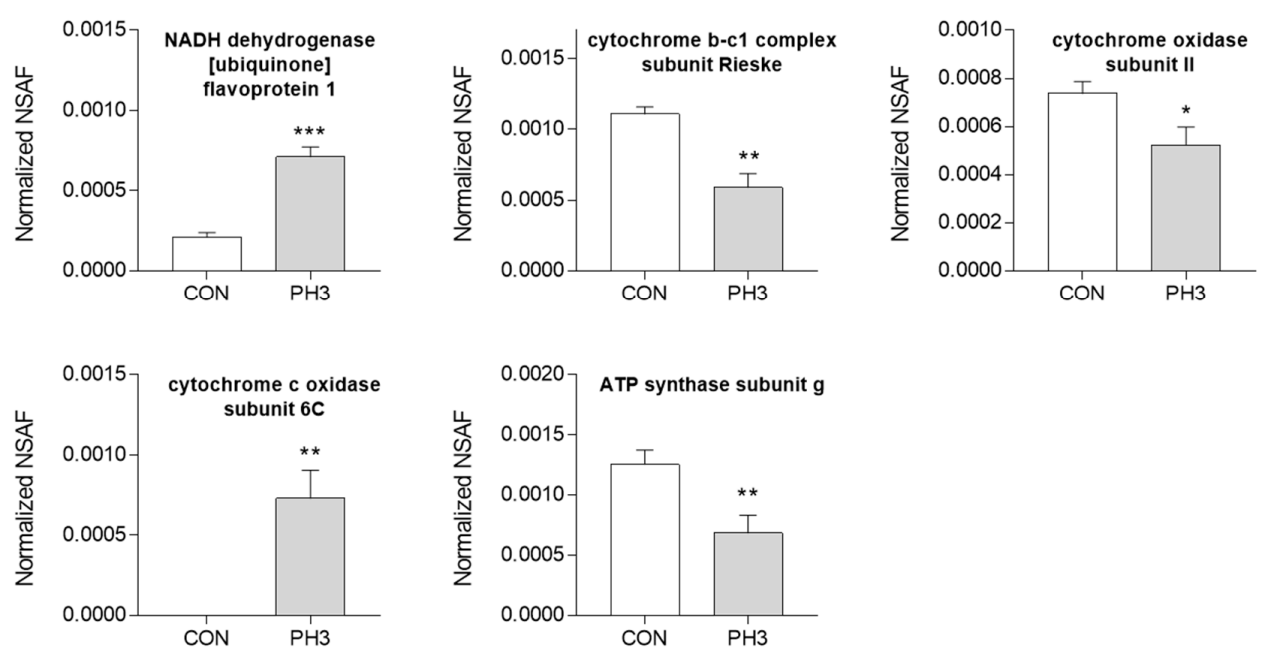

\section{(B) Defense}
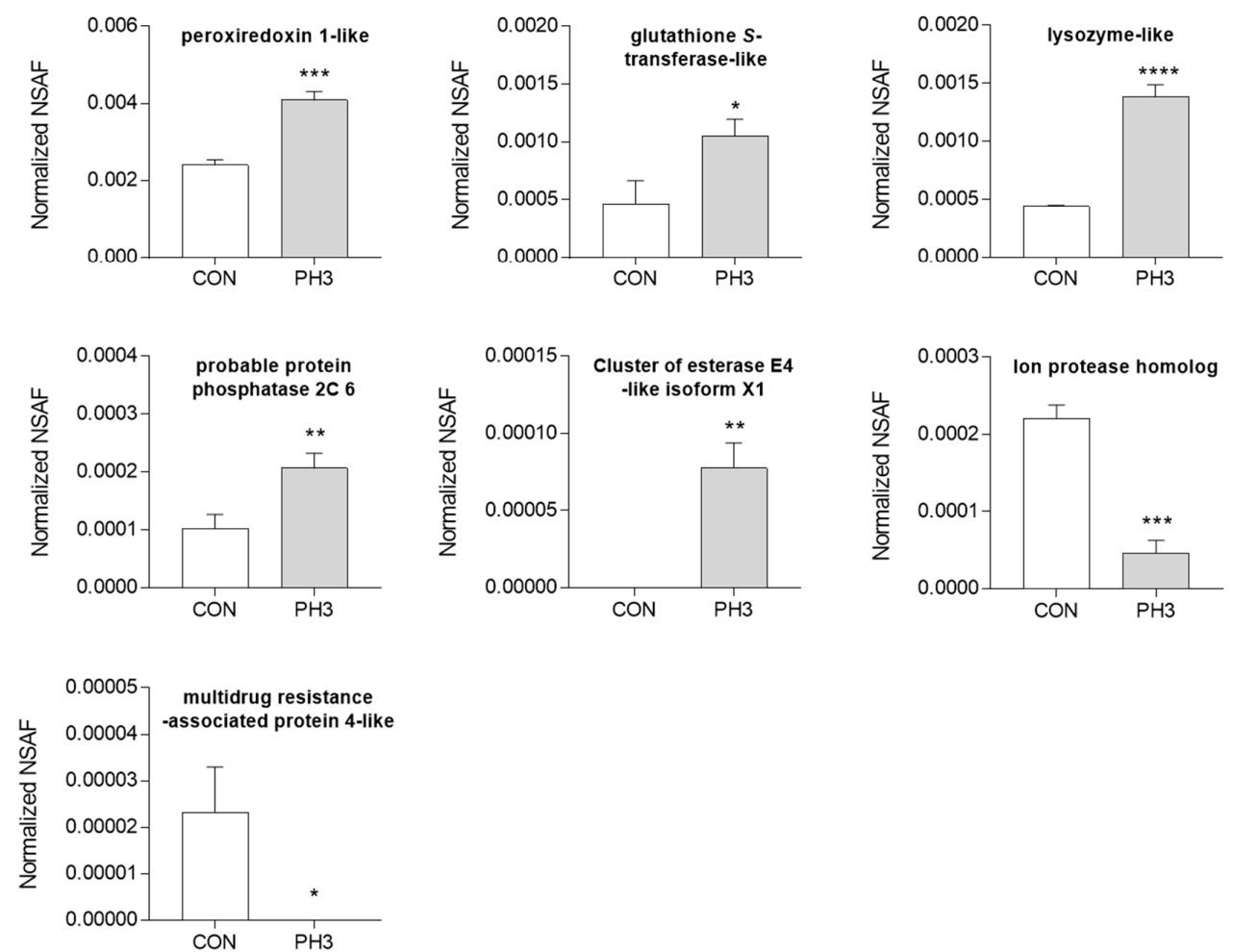

Figure 4. Cont. 


\section{(C) Metabolism}
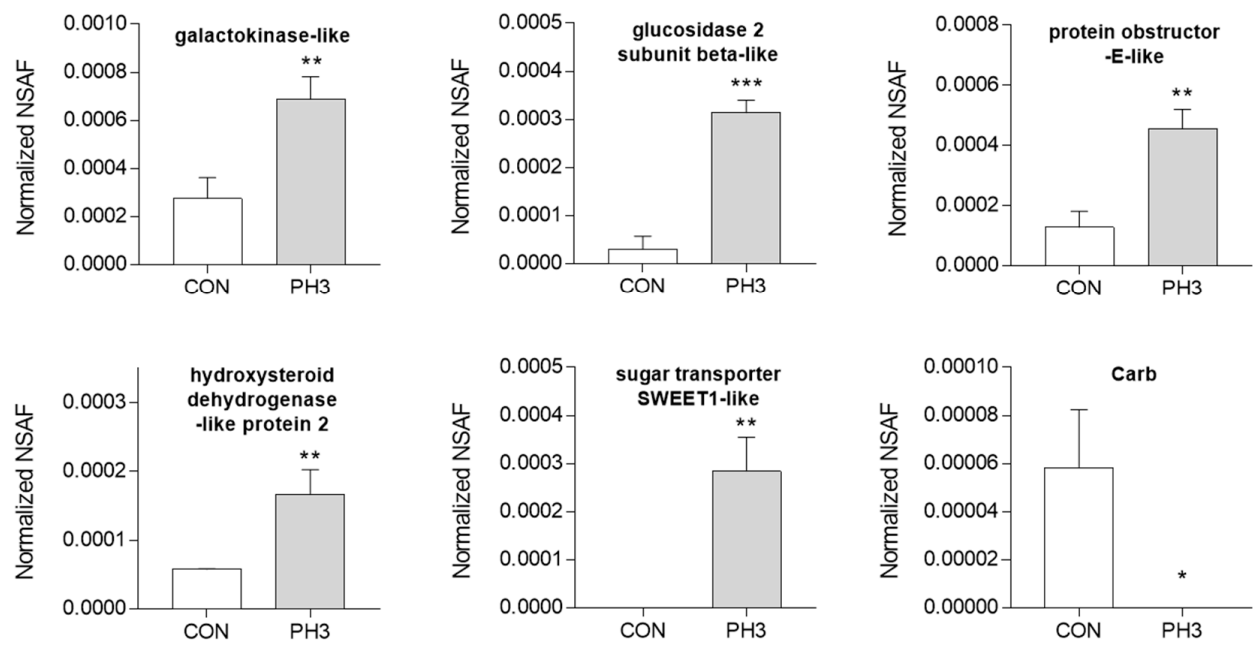

\section{(D) Others}
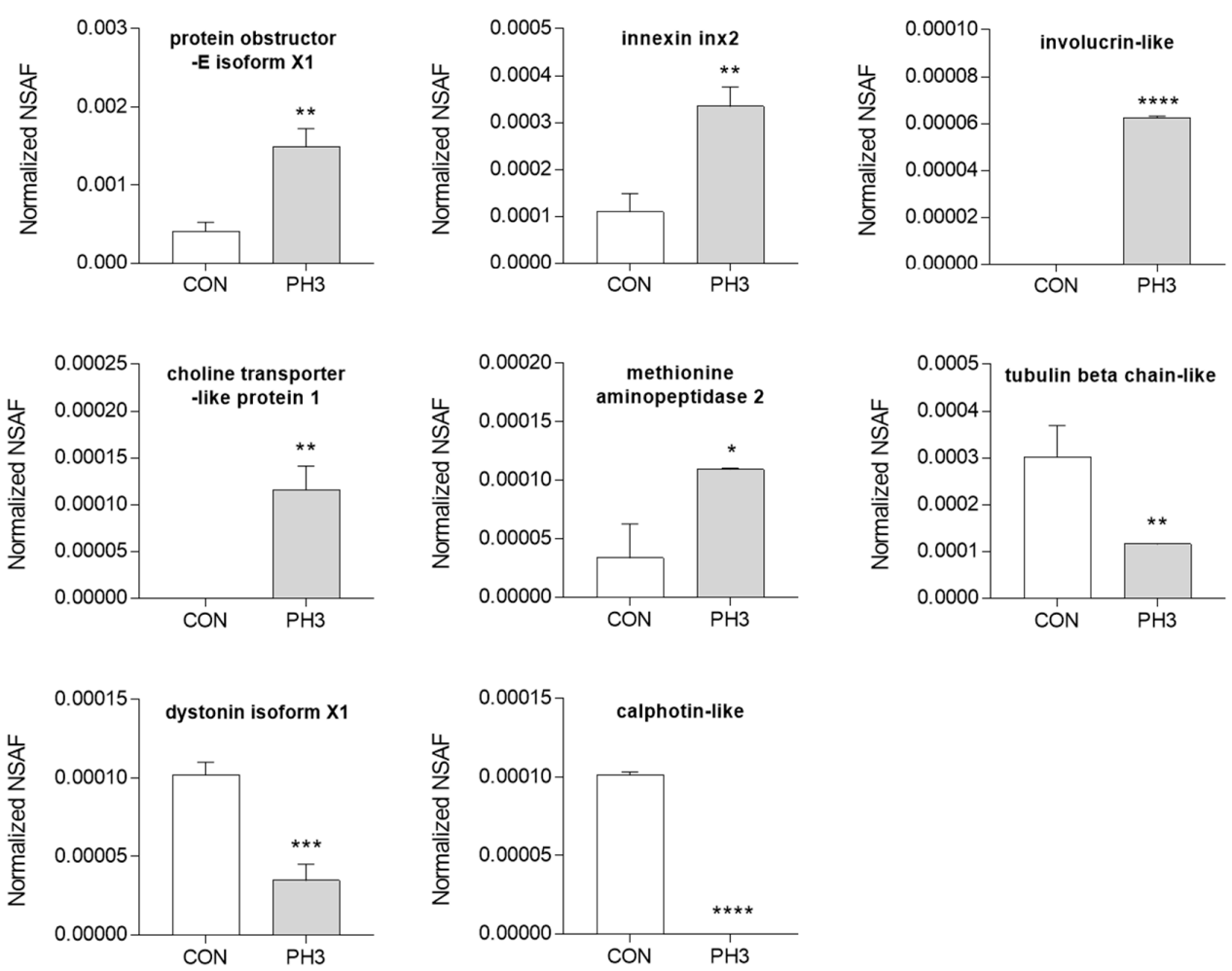

Figure 4. Proteins differentially expressed in adults of Myzus persicae after phosphine treatment at the concentration of $0.5 \mathrm{mg} / \mathrm{L}$ for $4 \mathrm{~h}$. CON; control treatment group, PH3; phosphine treatment group. Statistically difference was analyzed using $t$-test $(p<0.05) .{ }^{*},<0.05 ;{ }^{* *}, 0.01 ;{ }^{* * *}, 0.001 ;{ }^{* * * *}, 0.0001$. (A), proteins involved in energy metabolism, especially electron transport chain; (B), proteins involved in defense; (C), proteins involved in metabolism; (D), other proteins. 


\section{(A) Chromatin and histone}
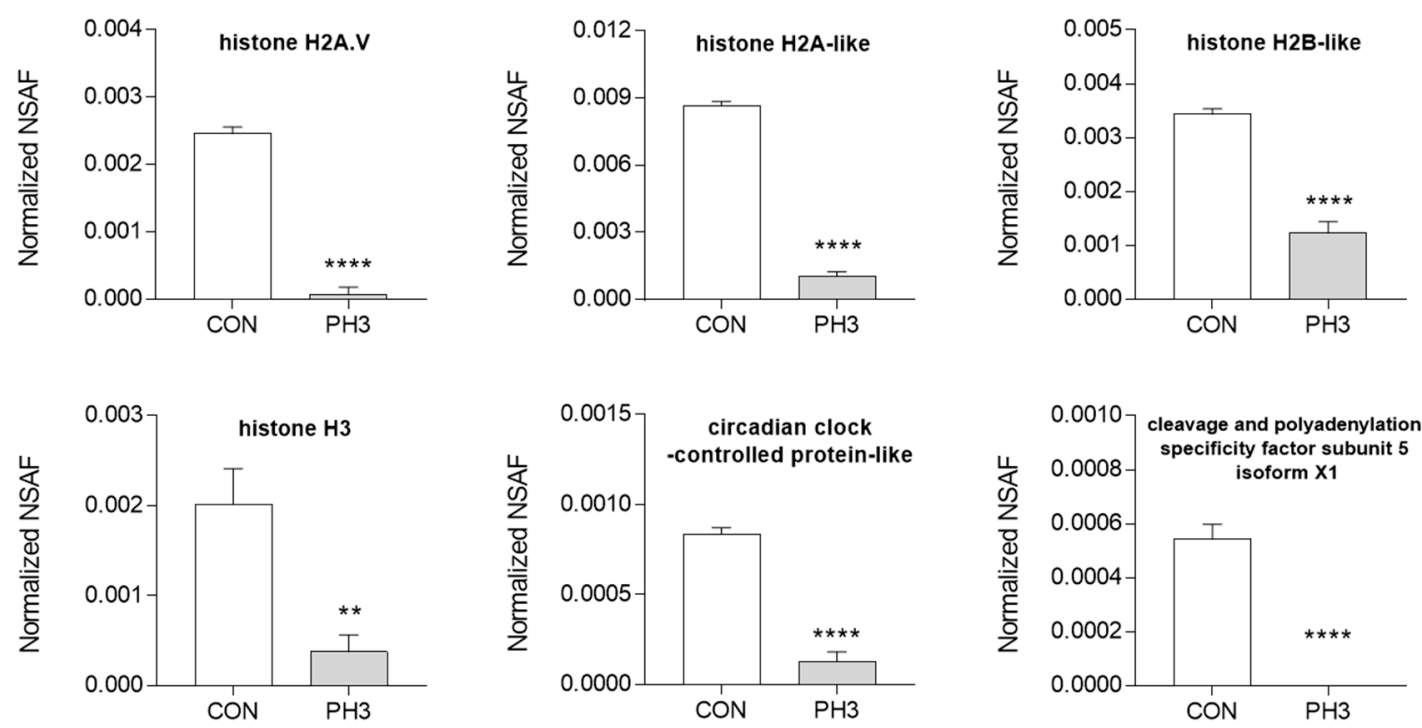

\section{(B) Transcription}
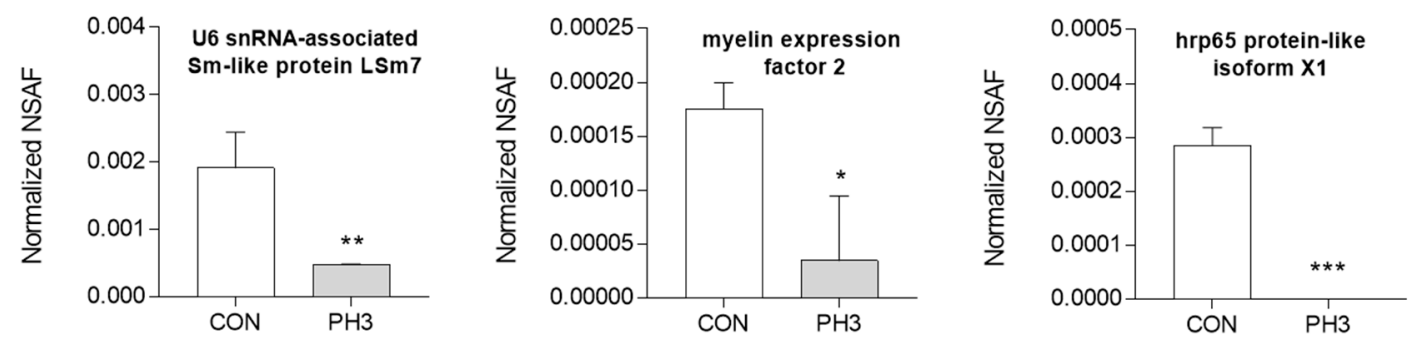

\section{(C) Translation and post-translational modification}
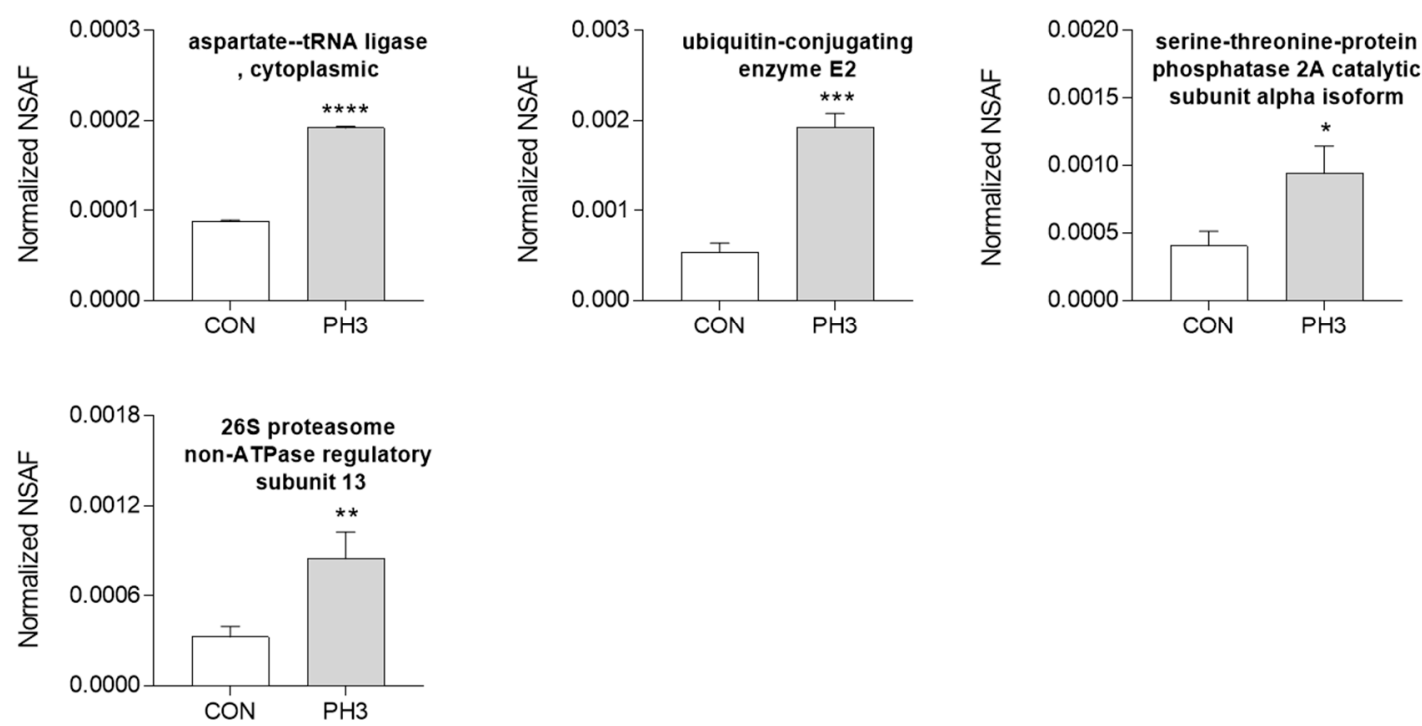

Figure 5. Cont. 


\section{(D) Signaling pathway}
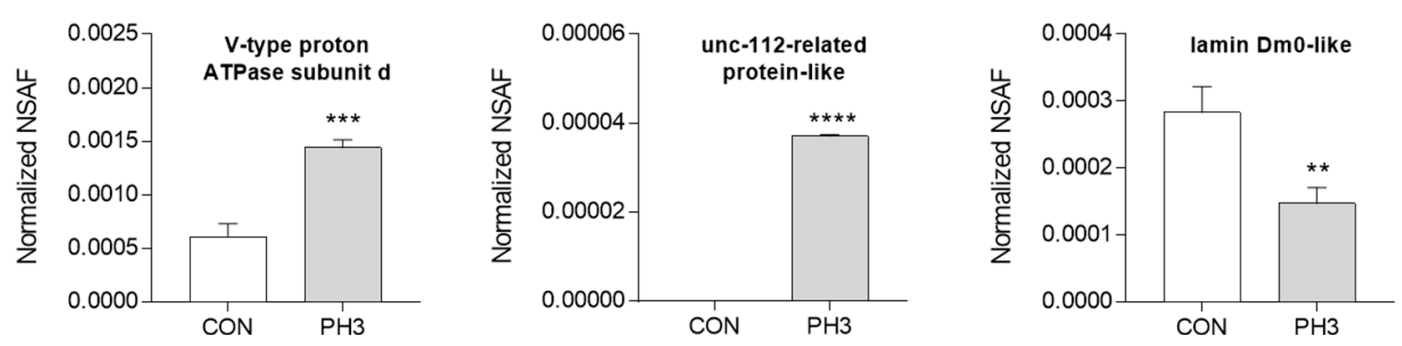

\section{(E) Others}
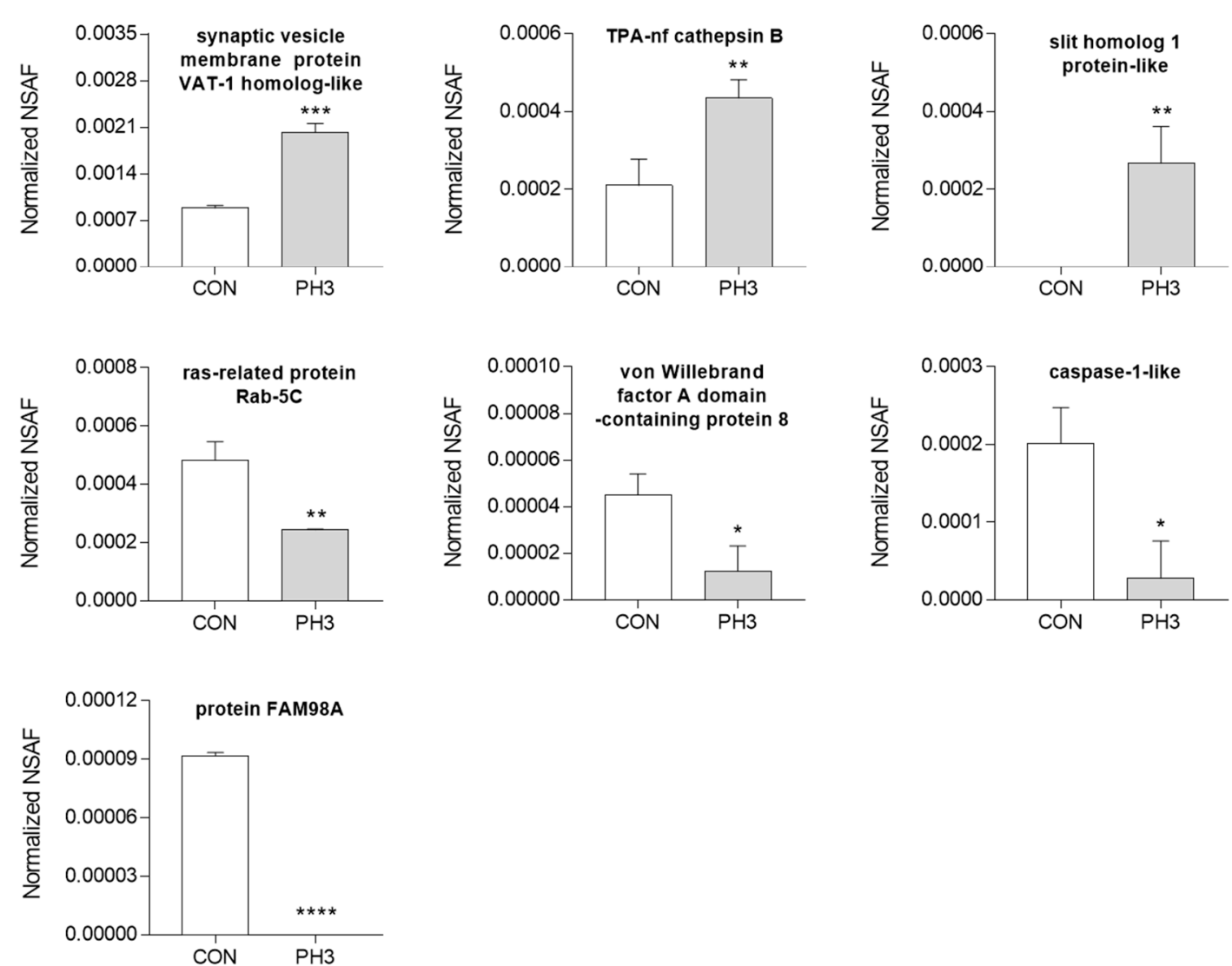

Figure 5. Proteins differentially expressed in adults of Myzus persicae after phosphine treatment at the concentration of $0.5 \mathrm{mg} / \mathrm{L}$ for $4 \mathrm{~h}$. CON; control treatment group, PH3; phosphine treatment group. Statistically difference was analyzed using $t$-test $(p<0.05) .{ }^{*},<0.05 ;{ }^{* *}, 0.01 ;{ }^{* * *}, 0.001$; $* * * *, 0.0001$. (A), proteins classified in chromatin and histones; (B), proteins involved in transcription; (C), proteins involved in translation and post-translational modification; (D), proteins involved in signaling pathways; (E), other proteins.

The primary changes in protein expression after $\mathrm{PH}_{3}$ treatment in M. persicae were found in the proteins of the respiratory system, including the upregulated NADH dehydrogenase (ubiquinone) flavoprotein 1 ( $\times 3.35$-fold), cytochrome b-c1 complex subunit Rieske $(\times 0.53$-fold), and the ATP synthase subunit $g(\times 0.54$-fold $)$ (Figure $4 \mathrm{~A})$. Cytochrome oxidase subunit II involved in ETC were also changed, but its change was not dramatic when compared to the control $(\times 0.70$-fold) (Figure $4 \mathrm{~A})$.

Some of the defense proteins, glutathione S-transferase-like $(\times 2.26$-fold $)$, lysozyme-like $(\times 3.14$-fold), probable protein phosphatase $2 \mathrm{C} 6(\times 2.02$-fold $)$, and clusters of esterase E4-like isoform $\mathrm{X} 1$ were highly upregulated in $\mathrm{PH}_{3}$-treated $M$. persicae. However, multidrug resistance-associated 
protein 4-like was found to be reduced in $\mathrm{PH}_{3}$-treated M. persicae (Figure 4B). Interestingly, the expression of several carbohydrate-related proteins in response to the $\mathrm{PH}_{3}$ treatment were also varied: galactokinase-like $(\times 2.2$-fold), glucosidase 2 subunit beta-like $(\times 10.3$-fold $)$, and sugar transporter SWEET1-like (Figure 4C).

On the contrary, histone H2A-like $(\times 0.19$-fold), histone H2B-like $(\times 0.35$-fold $)$, histone H2A.V $(\times 0.032$-fold), histone $\mathrm{H} 3(\times 0.19$-fold $)$, which are highly alkaline proteins in eukaryotic cells, and circadian clock-controlled protein-like $\left(\times 0.17\right.$-fold) were dramatically down-regulated in $\mathrm{PH}_{3}$-treated M. persicae (Figure 5A).

Various regulatory proteins, myelin expression factor $2(\times 0.20$-fold, Figure $5 \mathrm{~B})$, aspartate-tRNA ligase, cytoplasmic $(\times 2.18$-fold, Figure 5 C), ubiquitin-conjugating enzyme E2 $(\times 3.60$-fold, Figure $5 C)$, viz., type proton ATPase subunit d ( $\times 2.38$-fold, Figure 5D), lamin Dm0-like $(\times 0.52$-fold, Figure 5D), ras-related protein Rab-5C ( $\times 0.51$-fold, Figure 5E), caspase-1-like $(\times 0.14$-fold, Figure 5E), and cathepsin $\mathrm{B}\left(\times 2.07\right.$-fold, Figure 5E) were differentially expressed in $M$. persicae after $\mathrm{PH}_{3}$ treatment.

After $\mathrm{PH}_{3}$ treatment, some regulatory proteins were newly produced, viz. slit homolog 1 protein-like, and the expression of some were completely reduced, viz., of cleavage and polyadenylation specificity factor subunit 5 isoform X1, calphotin-like, and protein FAM98A (Figure 5).

\section{Discussion}

$\mathrm{PH}_{3}$ toxicity has been widely studied using its target invertebrates, including stored products insect pests, to understand how it disrupts normal physiological functions, leading to death [10-12]. A recent paper by Nath et al. [17] reviewed the two major routes of $\mathrm{PH}_{3}$ toxicity; an energy imbalance via the breakdown of the electron transport system in mitochondria, and metabolic disturbance. Other toxic mechanisms by which $\mathrm{PH}_{3}$ acts have been identified in rats and other mammals, such as a neurological disorder via potent inhibition on AChE activity, and severe inhibitory effects on metalloproteins, such as catalases and COX [18].

Prior to an amassing a deeper understanding of $\mathrm{PH}_{3}$ toxicity in M. persicae, many studies showed that $\mathrm{PH}_{3}$ interfered with COX activity, which is known as complex III in the electron transport chain $[18,19]$. Cytochrome $\mathrm{c}$ cox is a hemeprotein, within which $\mathrm{PH}_{3}$ can easily form coordination bonds with the ferric ions, thereby reducing COX activity to produce less ATP than normal [18].

In our study, M. persicae was exposed to low $\mathrm{PH}_{3}$ concentrations as $\mathrm{LCT}_{10}$ value ( $\mathrm{LC}_{10}$ value), which did not kill M. persicae. As shown in Figure 2, in the $\mathrm{PH}_{3}$-treated adults M. persicae COX activity decreased with increasing concentrations of $\mathrm{PH}_{3}$. However, this does not indicate that a direct inhibition of $\mathrm{PH}_{3}$ on the target site of $\mathrm{COX}$ occurred or there was an indirect inhibition of COX activity by $\mathrm{PH}_{3}$. LC-MS/MS analysis showed that COX expression decreased after $\mathrm{PH}_{3}$ treatment (Figure $4 \mathrm{~A}$ ). Therefore, a reduction in COX activity after $\mathrm{PH}_{3}$ treatment was related to the reduced expression of the corresponding protein in M. persicae. This result was confirmed by Chaudhry and Price [18], who showed that no spectral changes with $\mathrm{COX}$ were found after the $\mathrm{PH}_{3}$ treatment, indicating that there was no direct or weak contact between the $\mathrm{COX}$ protein and $\mathrm{PH}_{3}$ molecules. On the contrary, other hemeproteins, hemoglobin, and myoglobin showed slow deoxygenation with spectral changes after $\mathrm{PH}_{3}$ treatment [18].

Interestingly, changes in COX activity were not dramatic, whereas cytochrome b-c1 complex subunit Rieske and ATP synthase subunit $\mathrm{g}$ in the $\mathrm{PH}_{3}$-treated M. persicae decreased by around 0.5-fold in terms of protein expression when compared with the control. Similarly, a reduction in ATP synthase was confirmed by Liu et al. [20], which showed a 0.15-fold change in $\mathrm{PH}_{3}$-treated larvae of the peach fruit moth, Carposina sasakii Matsumura, using 2-dimesional electrophoresis with the MALDI-TOF MS analysis.

In this study, the most important finding is the dramatic change in NADH dehydrogenase (ubiquinone) flavoprotein $1(\times 3.35$-fold), which is complex I in the electron transport chain. It may be the first evidence that this protein is involved in $\mathrm{PH}_{3}$ toxicity in M. persicae. The ETC in the $\mathrm{PH}_{3}$-treated 
M. persicae was largely modified and the imbalance in ATP production was probably related to the metabolic disorder, leading to death of M. persicae.

However, regarding the up-regulation of NADH dehydrogenase (ubiquinone) flavoprotein 1 (complex I), one possible cause of $\mathrm{PH}_{3}$ toxicity may be the overproduction of reactive oxygen species (ROS). As ROS are primarily generated in the mitochondrial ETC, complexes I and III are major sites for the production of small quantities of ROS [20,21]. Normally, the generated ROS is converted to hydrogen peroxide by superoxide dismutase, and then hydrogen peroxide can be transformed to water by peroxidases, which $\mathrm{PH}_{3}$ inhibits in Sitophilus granarius [22]. Therefore, more ROS formation will probably occur in response to the up-regulation of complex I after $\mathrm{PH}_{3}$ fumigation, and this $\mathrm{ROS}$ generation can lead to the death of $M$. persicae during $\mathrm{PH}_{3}$ fumigation. In addition to this oxidative stress, one of the regulatory proteins, ion protease homolog in mitochondria, was down-regulated and it is involved in maintaining protein quality and controlling the occurrence of misfolded or incompletely synthesized proteins (Figure 4A). We need to further study the role of proteins in $\mathrm{PH}_{3}$ toxicity in M. persicae.

During $\mathrm{PH}_{3}$ treatment, M. persicae experienced induced expression of defense-related proteins including glutathione S-transferase-like $(\times 2.26$-fold $)$, lysozyme-like $(\times 3.14$-fold $)$, probable protein phosphatase 2C $6(\times 2.02$-fold), and a cluster of esterase E4-like isoform X1 (Figure 4B). These are involved in chemical detoxification (glutathione S-transferase-like and Cluster of esterase E4-like isoform X1) and antimicrobial properties (lysozyme-like and probable protein phosphatase 2C 6). Glutathione S-transferase-like and a cluster of esterase E4-like isoform X1 are easily found in organophosphorus insecticides (OP insecticides)-resistant M. persicae [23]. Therefore, their up-regulation in $\mathrm{PH}_{3}$-treated M. persicae is related to the chemical structure of $\mathrm{PH}_{3}$ and this includes the phosphorus ion. However, they may not be involved with the actual mechanism of $\mathrm{PH}_{3}$ detoxification in the insect because $\mathrm{PH}_{3}$ does not have an ester bond for esterase or an electrophilic site for conjugation reaction by glutathione $S$-transferase.

However, there was no relationship between the inhibition of AChE activity and $\mathrm{PH}_{3}$ treatment in M. persicae in our study (Figure 2), even though $\mathrm{PH}_{3}$ inhibited AChE activity in Ephestia cautella (Lepidoptera: Pyralidae) [22]. This difference may be due to the low (equivalent to LCT10) concentration of $\mathrm{PH}_{3}$ in the treatments. Al-Hakkak et al. [24] used a series of concentrations of $\mathrm{PH}_{3}$ treatments, which could kill the pupae of Ephestia cautella. This phenomenon has been corroborated by Nayak and Collins [25], who showed that $\mathrm{PH}_{3}$ toxicity was influenced by concentration, in a study involving fumigation of Liposcelis bostrychophila. Therefore, at a low $\mathrm{PH}_{3}$ concentration, $\mathrm{AChE}$ activity will not be targeted in insects. Other neurologically related proteins, including neurotransmitter receptors and channels, were not affected by $\mathrm{PH}_{3}$ fumigation (Figure 3).

At low $\mathrm{PH}_{3}$ concentrations, various regulation signals such as synaptic vesicle membrane protein VAT-1 (negative regulation of mitochondrial fusion), V-type proton ATPase subunit d (regulation of macroautophagy), serine/threonine-protein phosphatase 2A catalytic subunit alpha isoform (positive regulation of apoptotic process), cathepsin B (regulation of apoptotic process), and slit homolog 1 protein-like (positive regulation of apoptotic process, response to cortisol), were turned on in M. persicae (Figures 4 and 5). This suggests that even low $\mathrm{PH}_{3}$ concentrations induce the apoptotic process in M. persicae.

Finally, metabolic changes in relation to $\mathrm{PH}_{3}$ toxicity were also observed with the up-regulation of glucosidase 2 subunit beta-like $(\times 10.3$-fold $)$ and galactokinase-like $(\times 2.20$-fold $)$, similar to findings by Nath et al. [17]. This may be the first study to show such dramatic increases in glucosidase in relation to $\mathrm{PH}_{3}$ toxicity.

\section{Conclusions}

The fumigation toxicity of low concentrations of $\mathrm{PH}_{3}$, equivalent to $\mathrm{LCT}_{10}$, which were not fatal to M. persicae was determined using LC-MS/MS proteomic analyses. At low concentrations of $\mathrm{PH}_{3}$ fumigation, the ETC in mitochondria was dramatically modified to up-regulate complex I, but 
down-regulate complex III and ATPase. Interestingly, changes in complex I were significant because it also produced ROS in cells. To maintain the function of the ETC during the up-regulation of complex I might jeopardize M. persicae to cast the attack of $\mathrm{ROS}$ during $\mathrm{PH}_{3}$ fumigation. Significant changes in metabolic and regulatory proteins were also found in $\mathrm{PH}_{3}$-treated M. persicae. Thus, in response to low concentration $\mathrm{PH}_{3}$ treatments, $M$. persicae experienced severe biochemical changes, including changes in energy production, and starch and glycogen breakdown.

Supplementary Materials: The following are available online at http:/ /www.mdpi.com/2076-3417/8/10/1764/s1, Figure S1. Mortality curve for the treatment of phosphine according to its concentration and fumigation duration towards Myzus persicae. (A), nymphs; (B), adults. Table S1. Primer list using RT-qPCR analysis. Table S2. Effects of phosphine fumigation on the different developmental stages of Myzus persicae. Table S3. Proteins differentially expressed in adults of Myzus persicae after phosphine treatment at the concentration of $0.5 \mathrm{mg} / \mathrm{L}$ for $4 \mathrm{~h}$. CON; control treatment group, $\mathrm{PH}_{3}$; phosphine treatment group. Proteomic analyses of Myzus persicae were undertaken using a Nano-LC-ESI-MS/MS technique. Statistical difference was analyzed using $t$-test $(p<0.05)$. Proteins were involved in energy metabolism (especially, electron transport chain), defense, metabolism, and other proteins. Table S4. Proteins differentially expressed in adults of Myzus persicae after phosphine treatment at the concentration of $0.5 \mathrm{mg} / \mathrm{L}$ for $4 \mathrm{~h}$. CON; control treatment group, PH3; phosphine treatment group. Proteomic analysis was conducted by a Nano-LC-MS/MS. Statistical difference was analyzed using $t$-test $(\mathrm{p}<0.05)$. Proteins are classified in chromatin and histones, transcription, transition, and post-translational modification, signaling pathways and other functional roles in cells.

Author Contributions: S.-E.L. and J.O.Y. conceived and designed all of the experiments; K.K. and J.S.P. performed the experiments; K.K. and S.-E.L. analyzed the results; and S.-E.L. wrote the paper.

Funding: This study was supported by a grant from the Animal and Plant Quarantine Agency of the Ministry of Agriculture, Food and Rural Affairs of the Republic of Korea (Z-1543086-2017-19).

Conflicts of Interest: The authors declare no conflict of interest.

\section{References}

1. Rajashekar, Y.; Vanitha Reddy, P.; Khamrunissa, B.; Leelaja, B.C.; Somiahnadar, R. Studies on aluminium phosphide tablet formulation. Pestology 2006, 30, 41-45.

2. Karunaratne, C.; Moore, G.A.; Jones, R.; Ryan, R. Phosphine and its effect on some common insects in cut flowers. Postharvest Biol. Technol. 1997, 10, 255-262. [CrossRef]

3. Hansson, D.; Morra, M.J.; Borek, V.; Eigenbrode, S.D. Green peach aphid [Myzus persicae (Sulzer) (Hemiptera: Aphididae)] control using Brassicaceae ethyl ester oil sprays. J. Appl. Entomol. 2013, 137, 330-339. [CrossRef]

4. Park, J.H.; Lee, H.S. Phototactic behavioral response of agricultural insects and stored-product insects to light-emitting diodes (LEDs). Appl. Biol. Chem. 2017, 60, 137-144. [CrossRef]

5. Andorno, A.V.; Lopez, S.N. Biological control of Myzus persicae (Hemiptera: Aphididae) through banker plant system in protected crops. Biol. Control 2014, 78, 9-14. [CrossRef]

6. Kim, K.; Lee, B.H.; Park, J.S.; Yang, J.O.; Lee, S.E. Biochemical mechanisms of fumigant toxicity by ethyl formate towards Myzus persicae nymphs. J. Appl. Biol. Chem. 2017, 60, 271-277. [CrossRef]

7. Stewart, J.K.; Mon, T.R. Commercial-scale vaccum fumigation with ethyl formate for postharvest control of the green peach aphid (Homoptera: Aphididae) on film-wrapped lettuce. J. Econ. Entomol. 1984, 77, 569-573. [CrossRef]

8. Lee, B.H.; Kim, H.M.; Kim, B.S.; Yang, J.O.; Moon, Y.M.; Ren, Y. Evaluation of the synergistic effect between ethyl formate and phosphine for control of Aphis gossypii (Homoptera: Aphididae). J. Econ. Entomol. 2016, 109, 143-147. [CrossRef] [PubMed]

9. Yang, J.; Park, Y.; Hyun, I.H.; Kim, G.H.; Kim, B.S.; Lee, B.H.; Ren, Y. A combination treatment using ethyl formate and phosphine to control Planococcus citri (Hemiptera: Pseudococcidae) on pineapples. J. Econ. Entomol. 2016, 109, 2355-2363. [CrossRef] [PubMed]

10. Afful, E.; Elliott, B.; Nayak, M.K.; Phillips, T.W. Phosphine resistance in North American field populations of the lesser grain borer, Rhyzopertha dominica (Coleoptera: Bostrichidae). J. Econ. Entomol. 2018, 111, 463-469. [CrossRef] [PubMed]

11. Rafter, M.A.; McCulloch, G.A.; Daglish, G.J.; Walter, G.H. Progression of phosphine resistance in susceptible Tribolium castaneum (Herbst) populations under different immigration regimes and selection pressures. Evol. Appl. 2017, 10, 907-918. [CrossRef] [PubMed] 
12. Tang, P.A.; Duan, J.Y.; Wu, H.J.; Ju, X.R.; Yuan, M.L. Reference gene selection to determine differences in mitochondrial gene expressions in phosphine-susceptible and phosphine-resistant strains of Cryptolestes ferrugineus, using qRT-PCR. Sci. Rep. 2017, 7, 7047. [CrossRef] [PubMed]

13. Opit, G.P.; Thomas, E.; Phillips, T.W.; Payton, M.E. Effectiveness of sulfuryl fluoride fumigation for the control of phosphine-resistant grain insects infesting stored wheat. J. Econ. Entomol. 2016, 109, 930-941. [CrossRef] [PubMed]

14. Subramanyam, B.; Li, X. Efficacy of ozone against phosphine susceptible and resistant strains of four stored-product insect species. Insects 2017, 8, 42. [CrossRef]

15. Ellman, G.L.; Courtney, K.D.; Andres, V.; Featherstone, R.M. A new and rapid colorimetric determination of acetylcholinesterase activity. Biochem. Pharmacol. 1961, 7, 88-95. [CrossRef]

16. Livak, K.J.; Schmittgen, T.D. Analysis of relative gene expression data using real-time quantitative PCR and the $2^{-\Delta \Delta \text { ct }}$ method. Methods 2001, 25, 402-408. [CrossRef] [PubMed]

17. Nath, N.S.; Bhattacharya, I.; Tuck, A.G.; Schlipalius, D.I.; Ebert, P.R. Mechanisms of phosphine toxicity. J. Toxicol. 2011, 494168. [CrossRef] [PubMed]

18. Chaudhry, M.Q.; Price, N.R. A spectral study of the biochemical reactions of phosphine with various haemproteins. Pestic. Biochem. Phys. 1990, 36, 14-21. [CrossRef]

19. Price, N.R. Some aspects of the inhibition of cytochrome c oxidase by phosphine in susceptible and resistant strains of Rhyzopertha dominica. Insect Biochem. 1980, 10, 147-150. [CrossRef]

20. Liu, T.; Li, L.; Li, B.; Zhang, F.; Wang, Y. Proteomic analysis of peach fruit moth larvae treated with phosphine. Front. Biosci. 2012, E4, 1780-1786. [CrossRef]

21. Ježek, P.; Plecitá-Hlavatá, L.; Smolková, K.; Rossignol, R. Distinctions and similarities of cell bioenergetics and the role of mitochondria in hypoxia, cancer, and embryonic development. Int. J. Biochem. Cell Biol. 2010, 42, 604-622. [CrossRef] [PubMed]

22. Bolter, C.J.; Chefurka, W. Extramitochondrial release of hydrogen peroxide from insect and mouse liver mitochondria using the respiratory inhibitors phosphine, myxothiazol, and antimycin and spectral analysis of inhibited cytochromes. Arch. Biochem. Biophys. 1990, 278, 65-72. [CrossRef]

23. Bass, C.; Puinean, A.M.; Zimmer, C.T.; Denholm, I.; Field, L.M.; Foster, S.P.; Gutbrod, O.; Nauen, R.; Slater, R.; Williamson, M.S. The evolution of insecticide resistance in the peach potato aphid, Myzus persicae. Insect Biochem. Mol. Biol. 2014, 51, 41-51. [CrossRef] [PubMed]

24. Al-Hakkak, Z.S.; Al-Azzawi, M.J.; Al-Adhamy, B.W.; Khalil, S.A. Inhibitory action of phosphine on acetylcholinesterase of Ephestia cautella (Lepidoptera: Pyralidae). J. Stored Prod. Res. 1989, 25, 171-174. [CrossRef]

25. Nayak, M.K.; Collins, P.J. Influence of concentration, temperature and humidity on the toxicity of phosphine to the strongly phosphine-resistant psocid Liposcelis bostrychophila Badonnel (Psocoptera: Liposcelididae). Pest Manag. Sci. 2008, 64, 971-976. [CrossRef] [PubMed] 